\title{
Estimation of the Levels of Fe in Wheat and Maize Flour Milled using Commercial Milling Machine and A Home Blender
}

\section{*11 KALAGBOR, IA; FYNEFACE, D; KORFII, U; OGAJI T; KPOONANYIE, F}

\author{
Department of Science Laboratory Technology, School of Applied Sciences \\ Ken Saro-Wiwa Polytechnic, P. M. B. 20 Bori. Rivers State Nigeria. \\ *Corresponding author email: ksinachi@yahoo.com
}

\begin{abstract}
Milling devices are among the most commonly used in our indigenous markets and homes and variety of elements such as $\mathrm{Cu}, \mathrm{Ni}, \mathrm{Zn}, \mathrm{Pb}, \mathrm{Ti}, \mathrm{Co}, \mathrm{Cr}, \mathrm{Al}, \mathrm{Si}$, and $\mathrm{Fe}$ are used in their manufacture and fabrication. Often times they are present as alloys. With prolonged processing, these metals are gradually introduced as contaminants in the food being processed. Wheat and maize were selected for this study due to their wide usage as sources of protein and carbohydrate in Nigeria and Africa in general. The samples were cleaned by picking out sand, stones and other impurities and ground using the commercial milling machine and a home blender and were digested with $\mathrm{HNO}_{3}$ and $\mathrm{HClO}_{4}$ in the ratio of $4: 1$ and analyzed using AAS. Average $\mathrm{Fe}$ concentration values for both wheat and maize samples milled with commercial milling machine is $13.53 \mathrm{mg} / \mathrm{kg}$ and $26.79 \mathrm{mg} / \mathrm{kg}$ respectively while samples milled with the home blender gave concentration values of $4.00 \mathrm{mg} / \mathrm{kg}$ and $2.64 \mathrm{mg} / \mathrm{kg}$ for wheat and maize respectively. The high concentration of $\mathrm{Fe}$ in ground maize and wheat milled using the commercial milling machine could be attributed to the abrasive friction of the grinding disc as the grains come in contact with it during grinding resulting in its chipping off into the milled sample. It is therefore recommended that the commercial milling machine be redesigned with the incorporation of a permanent magnet to minimize or totally eliminate the introduction of $\mathrm{Fe}$ fillings into the ground grains and other foodstuffs. (C) JASEM

https://dx.doi.org/10.4314/jasem.v21i2.15
\end{abstract}

Keywords: Commercial milling machine, wheat, maize, contaminants, home blender, grinding

Mankind since early times had always milled using different milling techniques. These techniques varied in type and sophistication from one geographical location to another. The tradition, culture, and level of civilization also contributed to their milling tools. Contamination of food by heavy metals is of paramount concern to public health, as food is the primary source of essential nutrients for man (Pennington, 2000; Jigam, et al., 2011). The high level of contamination that results from these processing tools has detrimental consequences on human health. Depending on the heavy metal in question, toxicity occur at levels of just above naturally occurring background levels, meaning that consumption of foods with a high heavy metal concentration can cause acute or chronic poisoning (Llobet, et al., 2003). Human exposure occurs mainly from consumption of contaminated food. Cd exerts toxic effects on the kidney, the skeletal system and the respiratory system and it is classified as a human carcinogen (WHO, 2010). Poisoning can result in damaged or reduced mental and nervous functions, as well as damage blood composition, lungs, liver, kidney, and other vital organs. Long term exposure to heavy metals may result in slowly progressing physical, muscular, and neurological degenerative conditions as well as cancer (Llobet, et al., 2003). Sources of food contamination by heavy metals include techniques and materials used in food processing and transformation (Ehiri, et al., 2010; Dabonne, 2010). Due to numerous milling attributes, the determination of trace elements particularly heavy metal such as $\mathrm{Cr}, \mathrm{Fe}, \mathrm{Ni}, \mathrm{Co}, \mathrm{Pb}$, and $\mathrm{Cd}$ has received increasing attention in food chemistry, nutrition and pollution studies (Oyekale, et al., 2013). These metals vary in their properties with regard to workability, compatibility and sanitary design features. Depending upon the applications, various metals $(\mathrm{Zn}, \mathrm{Fe}, \mathrm{Al}, \mathrm{Cr}$, and $\mathrm{Mn}$ ) are used either in their alloy form or their elemental form (Ronald and Daniel, 2005) in the manufacture of most processing devices. The seriousness of any possible health issue is underscored by the fact that these grains are milled or ground with grinding devices for preparing various delicacies (Kwofie and Chandler, 2006). Food toxicity could be caused by trace elements as a result of local food processing. It could reach a significant stage, where it will be fatal with few exceptions, as nearly all foods consumed locally are milled before they are consumed. These metals are potential environmental contaminants with the capability of causing human health problems if present in excess 
in the food we eat (Salama and Mohammed, 2005). The parts of these milling devices are subject to wear and tear during use. It is therefore likely that they will introduce some particulates into the matrix of the foods/grains during processing (Yahaya et al., (2012), Wyasu et al., (2010), Bello et al., (2007)). The most frequently reported heavy metal with regard to potential hazard and occurrence in contaminated food samples are copper, lead, zinc, nickel, cobalt, chromium iron and cadmium (Ehiri et al., 2010). This study is designed to estimate the levels of $\mathrm{Fe}$ which is a major constituent in the manufacture of the grinding discs and blades of commercial milling machine and domestic blenders. Other metals ( $\mathrm{Cr}, \mathrm{Ni}, \mathrm{Co}, \mathrm{Cd}$ and $\mathrm{Pb}$ ) were also included in the investigation.

\section{MATERIALS AND METHODS}

Sample collection and preparation: The samples of wheat and maize were bought from oil mill market Port Harcourt in Rivers State, South-South region of Nigeria. These samples were cleaned by picking out sand, stones and other impurities. The cleaned samples were milled using the commercial milling machine in the four markets used in this study. The milled samples were put into separate containers and labeled accordingly. Another set of the samples were milled with the home blender and labeled properly.

Sample digestion: The ground samples were weighed, $2 \mathrm{~g}$ each into $250 \mathrm{ml}$ beakers and $10 \mathrm{ml}$ of the acid mixture of $\mathrm{HNO}_{3}$ and $\mathrm{HClO}_{4}(4: 1 \mathrm{v} / \mathrm{v})$ was added. The solution was stirred and heated over a low temperature hot plate in a fume cupboard for 4 hours to achieve complete digestion. The digested samples were allowed to cool, then distilled water was added and the samples filtered into beakers. The filtrate of each sample was transferred into $50 \mathrm{ml}$ volumetric flasks and then made up to mark with deionized water, and then transferred into clean sample bottles for AAS analysis.

Gravimetric analysis using magnetic bar: Equal weights $(2 \mathrm{~g}$ each) of the wheat and maize samples were weighed on filter papers and a bar magnet was used to stir each sample. After stirring, the samples (maize and wheat) were re-weighed and the differences in the known weight of the samples were recorded. Finally, the Fe particles in the bar magnet were cleaned with a filter paper into pre-weighed filter papers and the new weight of the filter was recorded. This was done for both wheat and maize samples. The difference was recorded for each sample of maize and wheat respectively:

$$
\begin{gathered}
\text { Weight of filter paper }=x m g \\
\text { Weight of filter paper and Fe particles in the sample }=\text { tmg } \\
\text { Weight of Fe particles added to the sample }=(t-x) m g
\end{gathered}
$$

\begin{tabular}{|c|c|c|c|c|c|}
\hline & \multicolumn{2}{|c|}{ Oil Mill } & \multirow{2}{*}{$\begin{array}{c}\text { GOKANA } \\
\text { Wheat }\end{array}$} & \multirow{2}{*}{$\frac{\text { MILE } 3}{\text { Wheat }}$} & \multirow{2}{*}{$\frac{\text { BORI }}{\text { Wheat }}$} \\
\hline & Wh & & & & \\
\hline Home & Sample 1 & 4.03 & 4.10 & 4.04 & 4.02 \\
\hline Blender & Sample 2 & 4.00 & 4.08 & 4.03 & 4.03 \\
\hline Mean & & 4.02 & 4.09 & 4.04 & 4.03 \\
\hline Std Dev. & & 0.02 & 0.01 & 0.01 & 0.01 \\
\hline Minimum & & 4.00 & 4.08 & 4.03 & 4.02 \\
\hline Maximum & & 4.03 & 4.10 & 4.04 & 4.03 \\
\hline Commercial & Sample 1 & 12.25 & 14.35 & 16.25 & 14.00 \\
\hline Milling Mach. & Sample 2 & 13.75 & 11.60 & 13.80 & 13.25 \\
\hline Mean & & 13.00 & 12.98 & 15.03 & 13.63 \\
\hline Std Dev. & & 1.06 & 1.94 & 1.73 & 0.53 \\
\hline Minimum & & 12.25 & 11.60 & 13.80 & 13.25 \\
\hline Maximum & & 13.75 & 14.35 & 16.25 & 14.00 \\
\hline & & Maize & Maize & Maize & Maize \\
\hline Home & Sample 1 & 2.50 & 2.60 & 2.50 & 2.50 \\
\hline Blender & Sample 2 & 2.75 & 2.67 & 2.75 & 2.75 \\
\hline Mean & & 2.63 & 2.64 & 2.63 & 2.63 \\
\hline Std Dev. & & 0.18 & 0.05 & 0.18 & 0.18 \\
\hline Minimum & & 2.50 & 2.60 & 2.50 & 2.50 \\
\hline Maximum & & 2.75 & 2.67 & 2.75 & 2.75 \\
\hline Commercial & Sample 1 & 27.75 & 43.00 & 17.50 & 19.50 \\
\hline Milling Mach. & Sample 2 & 30.25 & 36.87 & 16.75 & 22.75 \\
\hline Mean & & 29.00 & 39.94 & 17.13 & 21.13 \\
\hline Std Dev. & & 1.77 & 4.33 & 0.53 & 2.30 \\
\hline Minimum & & 27.75 & 36.87 & 16.75 & 19.50 \\
\hline Maximum & & 30.25 & 43.00 & 17.50 & 22.75 \\
\hline
\end{tabular}

\section{RESULTS AND DISCUSSION}

Table 1: Concentration of $\mathrm{Fe}(\mathrm{mg} / \mathrm{kg})$ in Wheat and Maize 
The results of AAS analysis for the levels of $\mathrm{Fe}$ present in the grain samples processed with commercial milling machine and the home blender are presented in Table 1. The concentration of $\mathrm{Fe}$ in the wheat samples milled with the home blender range from $4.00 \mathrm{mg} / \mathrm{kg}$ to $4.10 \mathrm{mg} / \mathrm{kg}$ and its concentration in the maize samples range from 2.50 $\mathrm{mg} / \mathrm{kg}$ to $2.75 \mathrm{mg} / \mathrm{kg}$. Samples milled at the Gokana market have the highest $\mathrm{Fe}$ concentrations for the home blender and the samples milled at the Mile 3 and Bori markets have the highest Fe concentrations for commercial milling machine. Wheat samples ground using the commercial milling machine has $\mathrm{Fe}$ concentrations ranging from $11.60 \mathrm{mg} / \mathrm{kg}$ to 16.25 $\mathrm{mg} / \mathrm{kg}$ while the maize samples have $\mathrm{Fe}$ concentrations of $16.75 \mathrm{mg} / \mathrm{kg}$ to $43.00 \mathrm{mg} / \mathrm{kg}$. The highest concentrations recorded for wheat using this milling device is the sample milled at Mile 3 market $(16.25 \mathrm{mg} / \mathrm{kg})$ and the highest recorded for maize is the sample milled at Gokana market $(43.00 \mathrm{mg} / \mathrm{kg})$. This result shows that $\mathrm{Fe}$ was introduced into the samples from the discs and blades of the grinding devices. The contamination is highest in maize samples milled with the commercial milling machine compared to that of the home blender. These high $\mathrm{Fe}$ concentrations agree with the finding of Kalagbor et al., (2016). This is so because in the manufacture of the grinding discs of the commercial milling machine, Fe is used due to its strength and durability. The composition of $\mathrm{Fe}$ in the commercial milling machine is more than that in the home blender. The high concentration of $\mathrm{Fe}$ in ground maize and wheat milled using commercial milling machine could be attributed to the abrasive friction of the grinding disc as the grains sample come in contact with it during grinding which results in its chipping off into the milled sample as observed and reported by Yahaya et al, (2012). It also shows that Fe contamination is more in maize using the commercial milling machine due to the higher number of times the maize was ground to obtain fine flour because of the hard kernels whereas wheat was ground for a shorter period of time. Therefore the presence of Fe in the samples is dependent on the elemental composition of the grinding discs of the commercial milling machine and domestic blender (Osei, 2001). Ronald and Daniel (2005) reported that various metals such as $\mathrm{Zn}, \mathrm{Fe}, \mathrm{Cr}, \mathrm{Al}$ and $\mathrm{Mn}$ are used in the manufacture of most processing devices. The results obtained from both milling devices are above the maximum acceptable limit given by the FAO/WHO standard. From the gravimetric analysis carried out using the magnetic bar, no results were obtained for the separation of $\mathrm{Fe}$ from the milled samples. This may be due to the low sensitivity of the bar magnet to pick up Fe fillings in $2 \mathrm{~g}$ samples as compared to the AAS.

Conclusion and Recommendation: The production of Fe fillings could be from the friction of the grinding plates, misalignment from the vertical position of the grinding plates and incorrect sharpening of these plates. It can be seen from the constituents of the composition of the grinding mills, that $\mathrm{Fe}$ was released into the food sample due to ageing and wearing of the grinding discs and other machine components. From these results, it also shows that we may have been ingesting little quantities of $\mathrm{Fe}$ as part of our daily diet. The grinding machine should have a compartment that will remove $\mathrm{Fe}$ filings introduced into the food sample ground by magnetization.

\section{REFERENCES}

Bello, I.A; Oke O; Ibrahim, A.O; Abdul R. (2007). Levels of cadium, lead and zinc introduced as contaminants into foods stuffs during processing Science Focus. 12(2) :1-5.

Dabonne, S; Koffi, B. P. K; Kouadio, E. J. P; Koffi, A. G; Due, E. A; Kouame, L. P. (2010). Traditional Utensils: Potential Sources of Poisoning by Heavy Metals. British Journal of Pharmacological and Toxicology 1(2): 90 -92.

Ehiri, D.C; Megwa, G. U; Omaka, N. O. (2010). Food Grinding Stones as a source of Heavy Metal Contamination of Diets. Journal of Sciences and Multidisciplinary Research. 2. http://www.cfa.uaeu.ac.ae/research/ejas.htm

Jigam, A. A., Bukar, E. N. D., Jimoh, T., Hauwa, N. Y. and Umar, Z. T., (2011). Determination of copper, zinc, lead and some biochemical parameters in fresh cow milk from different locations in Niger State, Nigeria. African Journal of Food Sciences. 5(3). 156- 160.

Kalagbor, I. A.; Abraham Z.; Mene, N.B; Uba; G.C; Don- Pedro, O; Osuamkpe, E; (2016). Levels of some metals contaminations of wheat, white beans, plantain and maize milled with domestic blender, hand grinder, wooden mortar and grinding stone. Presented at the $39^{\text {th }}$ Annual International Conference of Chemical Society of Nigeria in Port Harcourt $\left(18^{\text {th }}-23^{\text {rd }}\right.$ September, 2016)

Kwofie, S; Chandler, H.D. (2006) Potential Health Effects of Locally Manufactured corn mill Grinding Plates. J. Sc and Tech. 26(2): 137-147. 
Llobet, J. M; Falco, G; Casas, G; Teixido, A; Domingo, J. L (2003). Concentrations of Arsenic, Cadmium, Mercury and Lead in common Foods and Estimated Daily Intake by Children, Adolescents, Adults and Seniors of Catalonia, Spain. Spain Journal of Agricultural Food Chemistry. 51: 838-842.

Ojekale, B. A; Chukwu, C.G; Lawal, O.O.; Osinake, T.S (2013). Some Nigeria Traditional Food Milling Techniques and Cookware. Isor Journal of Pharmacy. 3(3): 6-13.

Osei, Y. A. (2001). New School Chemistry for Senior Secondary Schools. Revised Edition, Africana First Publishers Ltd. Nigeria.

Pennington, J. A. T (2000). Total Diet Studies Experiences in the United States. Journal of Food Composite Analysis. 13: 539-544.

Ronald, H. S; Daniel, J. E. (2005). Sanitary Design and Construction of Food Equipments. IFAS Extention, University of Florida.
Salama, K.A; Mohamed, A.R.(2005). Heavy Metals $(\mathrm{Cd}, \mathrm{Pb})$ and Trace Elements $(\mathrm{Cu}, \mathrm{Zn})$ Contents in Some Food Stuffs from Egyptian Market. Emirate Journal of Agricultural Sciences. 17(1). 34-42.

WHO (2010). Exposure to Cadmium: A Major Public Health Concern. Preventing Disease through Healthy Environments. World Health

Organization. 1: 317-319. http://www.who.int

Wyasu, G; Onoja, E.; Omeiza, F.S., (2010). Comparative Analysis of the Level of Lead and Cadmuim Contaminations of Food During Processing With Atlas Machine as a Local Grinding Stone. Achieves of Applied Sciences Research. 2(5). 331-336.

Yahaya, D.B; Aremu, D.A.; Abdullahi. I,. (2012). Investigation of Metals Contaminates in Locally Ground Food (Beans as Tomatoes). Journal of Emerging Trends in Engineering and Applied Sciences. 3(1):331-343 